\title{
OPTIMALIZÁCIA VÝBERU NÁSTROJOV KOMUNIKAČNÉHO MIXU PODNIKU S VYUŽITÍM PROGRAMU EXPERT CHOICE
}

\author{
Viera Frianová*
}

\section{Úvod}

Rozhodovanie patrí bezpochyby medzi najdôležitejšie a zároveň najt’ažšie úlohy manažérov a riadiacich pracovníkov podnikov a organizácií. Nájdenie optimálneho rozhodnutia si často vyžaduje uskutočnit’ mnohovariantné ako aj viackriteriálne posúdenie. To znamená, že jednotlivé varianty, ako objekty rozhodovacieho procesu, sú manažéri často nútení posúdit' a vyhodnotit' na základe viacerých kritérií, pričom usporiadanie variantov je spravidla podl'a každého kritéria iné, navyše jednotlivé kritériá sa často vyznačujú diferencovanou mierou dôležitosti.

Podniky, ktoré uplatňujú marketingovú koncepciu riadenia sú nútené riešit' množstvo rozhodovacích problémov súvisiacich práve s využívaním ich marketingového inštrumentária. Integrálnou súčast'ou (jednou z kontrolovatel'ných premenných) marketingového mixu podnikov je aj marketingová komunikácia, ktorej úlohou je ponúknut' také nástroje a formy komunikácie, ktoré by boli v danej situácii pre podnik vhodné natol'ko, aby ich využitím získal žiaduce efekty. Podnik tak neraz stojí pred rozhodovacím problémom, ktoré nástroje/formy marketingovej komunikácie s ohl'adom na konkrétnu situáciu a svoje komunikačné potreby do svojho komunikačného mixu zaradit', aby boli dosiahnuté stanovené ciele a bolo možné komunikáciu podniku považovat' za úspešnú a efektívnu. Ak podnik v danej oblasti nevyužíva služby externých odborníkov (napr. pracovníkov špecializovaných agentúr), jeho rozhodovanie sa často opiera len o nadobudnuté skúsenosti, vedomosti, schopnosti, prípadne intuíciu interných zamestnancov - najmä pracovníkov marketingového oddelenia ako aj manažérov podniku. Čím vzniká reálna hrozba, že rozhodnutie v danej oblasti nebude objektívne. Ked’že pri viackriteriálnom hodnotení variantov možno konečný výsledok ovplyvnit' jednak výberom kritérií ako aj prisúdením váhy jednotlivým kritériám váhy kritérií majú subjektívny charakter, závisiaci od použitej metódy ako aj od samotného hodnotitel'a, s ciel'om objektivizovat' rozhodovací proces a zároveň podporit' rozhodovanie sa podniku pri výbere nástrojov, ktoré by tvorili jeho optimálny komunikačný mix, odborníci odporúčajú využitie exaktných matematických metód. Tieto sú z dôvodu časovej a technickej náročnosti často implementované do počítačových programov. V nasledujúcom texte sa pokúsime na modelovom príklade prezentovat' postup zostavenia optimálneho komunikačného mixu podniku s využitím počítačového programu Expert Choice.

\footnotetext{
* Ing. Viera Frianová, Katedra manažmentu, Akadémia ozbrojených síl gen. M. R. Štefánika, Demänová 393, 03101 Liptovský Mikuláš tel.: +420960423525

e-mail: viera.frianova@aos.sk
} 


\section{Program Expert Choice a jeho základné prvky}

Program Expert Choice určený na podporu multikriteriálneho rozhodovania pomáha pri rozhodovaní o výbere z alternatív, ktoré sú charakteristické hierarchickým rozložením kritérií a priorít pre výber. Program pritom využíva Saatyho metódu analytických hierarchických procesov (AHP), ktorá ul'ahčuje rozhodovanie pri stanovení dôležitosti rôznych ciel'ov a ich preferencií $\mathrm{v}$ rôznych alternatívach riešenia (uvedená metóda je považovaná za jeden zo základných pilierov operačného výskumu) [1]. Východiskom pre aplikáciu Saatyho metódy je konštrukcia tzv. Saatyho matice:

$\mathbf{A}=\left(\mathbf{a}_{\mathbf{i j}}\right)_{\mathbf{n}}{ }^{\mathbf{n}}$, kde $\mathrm{n}$ je počet porovnávaných objektov (kritérií, variantov).

Prvky tejto matice udávajú intenzitu preferencie všetkých dvojíc porovnávaných objektov podla nasledovnej bodovej stupnice, kde $\mathrm{v}_{\mathrm{i}}$ a $\mathrm{v}_{\mathrm{j}}$ predstavujú váhu príslušného objektu:

$\begin{array}{ll}\text { intenzita preferencie } & \text { deskriptor } \\ 1 & \mathrm{v}_{\mathrm{i}} \text { má rovnakú dôležitost' } a k o \mathrm{v}_{\mathrm{j}} \\ 3 & \mathrm{v}_{\mathrm{i}} \text { sa slabo preferuje pred } \mathrm{v}_{\mathrm{j}} \\ 5 & \mathrm{v}_{\mathrm{i}} \text { sa silno preferuje pred } \mathrm{v}_{\mathrm{j}} \\ 7 & \mathrm{v}_{\mathrm{i}} \text { sa preukázatel'ne preferuje pred } \mathrm{v}_{\mathrm{j}} \\ 9 & \mathrm{v}_{\mathrm{i}} \text { je absolútne dôležitejšie ako } \mathrm{v}_{\mathrm{j}} \\ 2,4,6,8 & \text { medzistupne preferencií }\end{array}$

Podrobný algoritmus Saatyho metódy neuvádzame, je možné sa s ním bližšie oboznámit' v dostupnej literatúre [2].

K základným prvkom programu Expert Choice patria: varianty, kritériá, priority a preferencie. Varianty (alternatívy) sú hodnotené možnosti riešenia rozhodovacieho problému, resp. zamenitel'né riešenia problému, zabezpečujúce rovnaký účel splnenie zadaného ciel'a. Hodnotenie sa realizuje na základe kritérií stanovených pre výber s požadovanými prioritami dôležitosti. Ciel'om rozhodovania je stanovit' poradie na základe výpočtu vzájomných preferencií a na základe toho vybrat' najvhodnejší (optimálny) variant riešenia rozhodovacieho problému. Kritériá sú všetky vlastnosti, parametre a ostatné údaje jednotlivých variantov, ktoré majú vplyv na rozhodovanie o výbere najvhodnejšieho variantu. Sú to hl'adiská, z ktorých sú jednotlivé varianty posudzované. Spravidla majú hierarchickú štruktúru, vymedzujú sa od všeobecných k detailnejším. Môžeme ich získat' napr. na základe expertných odhadov, štatistických údajov, zo špecializovaných agentúr atd'. Priority charakterizujú vzt’ahy medzi jednotlivými kritériami, teda majú vplyv na celkové vyhodnotenie jednotlivých variantov. Stanovujú sa podl'a dôležitosti jednotlivých kritérií pre splnenie ciel'a, pričom celkový súčet hodnôt priorít na rovnakej úrovni kritérií je vždy $100 \%$. Preferencie vyjadrujú vzájomnú výhodnost' (váhu) pri párovaní kritérií medzi dvojicami alternatív. Pri hodnotení variantov hodnotiaci postupne stanovuje vel'kosti preferencií jednotlivých dvojíc variantov pre každé hodnotiace kritérium. Určením vzájomných preferencií jednotlivých alternatív $\mathrm{v}$ rámci kritérií a ich priorít dostaneme výsledné preferencie jednotlivých alternatív. Program Expert Choice využíva metódu párového porovnávania kritérií v rámci stanovených priorít. Hierarchicky členené kritériá a ich priority program umožňuje zaznamenat' do modelu. Zároveň zlučuje hierarchické priority do celkových priorít všetkých hodnotených alternatív riešeného problému [3]. 


\section{Východisková modelová situácia}

V modelovom príklade sme vychádzali z nasledovnej fiktívnej situácie. Podnik služieb vol'ného času a animácie v cestovnom ruchu (strednej vel'kosti) s celoročnou prevádzkou zameraný na pohybovo-športovú, spoločenskú a zábavno-relaxačnú činnost' zaznamenal v určitom období roka (mimo hlavnej letnej sezóny) pokles návštevnosti, a teda aj využitia svojich kapacít. Uvedené negatíva sa vel'mi rýchlo prejavili vo výraznejšom poklese tržieb z predaja služieb daného podniku. Podnik predpokladá, že tento stav má len krátkodobý charakter. V snahe riešit' vzniknutú situáciu si manažment podniku stanovil nasledovný ciel': oslovit' a následne prilákat' prostredníctvom špeciálneho balíka služieb predávaného za zvýhodnenú cenu vybrané ciel'ové skupiny zákazníkov z regiónu, v ktorom je podnik situovaný (prípadne z jeho blízkeho okolia). Na základe uskutočnenej segmentácie trhu sa podnik rozhodol svoje marketingové úsilie sústredit' na nasledovné segmenty: dôchodcovia, študenti a rodiny s det'mi. Informovat' vybrané ciel'ové skupiny, stimulovat' ich dopyt a v konečnom dôsledku ich primät' ku kúpe produktu, si zo strany podniku vyžaduje realizáciu účinnej a efektívnej (s ohl'adom na značne obmedzený rozpočet na marketing najmä ekonomicky efektívnej) marketingovej komunikácie. Podnik sa tak ocitol pred rozhodovacím problémom: „ktoré nástroje marketingovej komunikácie v danej situácii využit"“? Pričom v súvislosti so spomínanou obmedzenou výškou finančných prostriedkov na aktivity v oblasti MK uvažuje o zostavení komunikačného mixu, ktorý by pozostával z 2-3 nástrojov marketingovej komunikácie. Svoje rozhodovanie o ich výbere sa rozhodol podporit' využitím programu Expert Choice.

\section{Postup aplikácie programu Expert Choice}

V prvom kroku práce s programom bolo potrebné do vstupných údajov pridat' jednotlivé varianty hodnotenia. V našom príklade sme pre zjednodušenie hodnotili len pät' nástrojov marketingovej komunikácie, a to: reklamu, podporu predaja, PR, osobný predaj a priamy marketing. Zadávanie jednotlivých variantov znázorňuje obrázok 1.

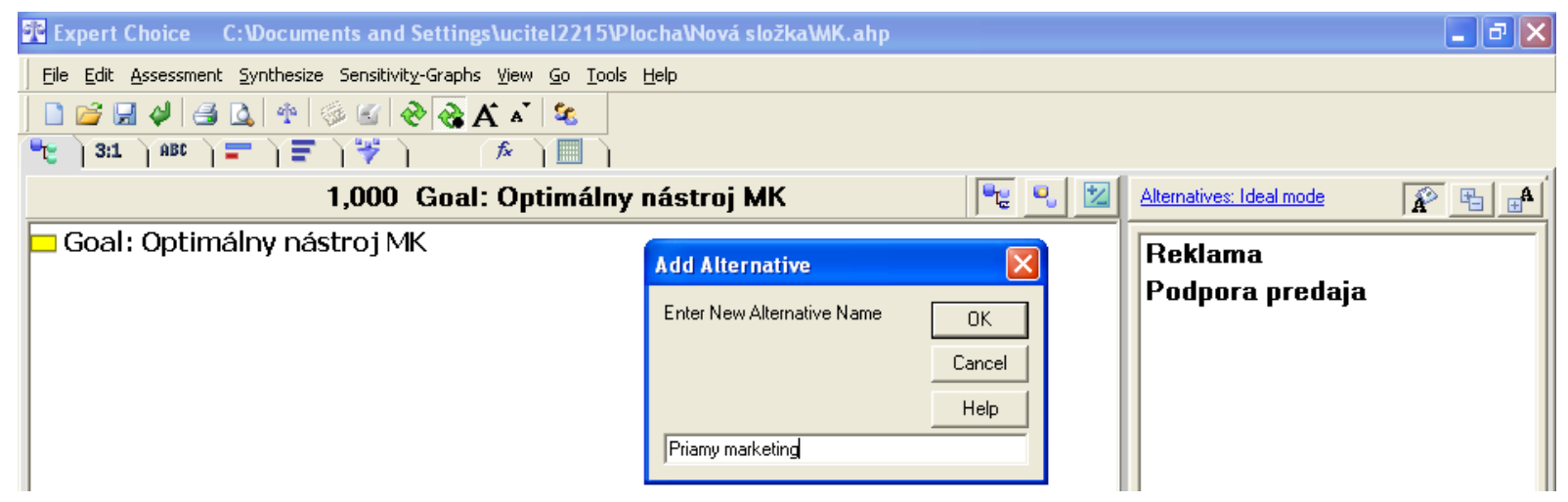

Obrázok 1 Ukážka zadávania variantov

Prameň: Výstup programu Expert Choice.

V druhom kroku bolo potrebné vybrat' kritériá, ktoré sa budú sledovat' a hodnotit'. Následne bolo potrebné stanovit' ich hierarchiu, teda každému zo sledovaných kritérií priradit' určitú prioritu/váhu (t. j. vyjadrit' relatívnu dôležitost' každého kritériá v porovnaní s ostatnými). V prezentovanom modelovom príklade je braná do úvahy len malá čast' zo skutočných možných kritérií hodnotenia jednotlivých nástrojov marketingovej komunikácie, pretože našim ciel'om nebolo zahrnút' do hodnotenia všetky možné kritériá, čo by prakticky 
ani nebolo možné, ale len ponúknut' návrh rozkladu možných kritérií. Je potrebné zdôraznit', že množina kritérií, ako aj ich štruktúra sa odvíja od individuálnych preferencií toho, kto rozhodovanie uskutočňuje. V našom príklade sme pri výbere kritérií hodnotenia vychádzali z publikovanej tabul'ky [4], ktorá porovnáva jednotlivé prvky marketingového komunikačného mixu vzhl'adom na vybrané parametre. Štruktúru usporiadania jednotlivých kritérií so znázornením ich priorít prezentuje obrázok 2 (dôležitost' jednotlivých kritérií je znázornená prostredníctvom vel'kostí výsekov jednotlivých koláčových grafov).

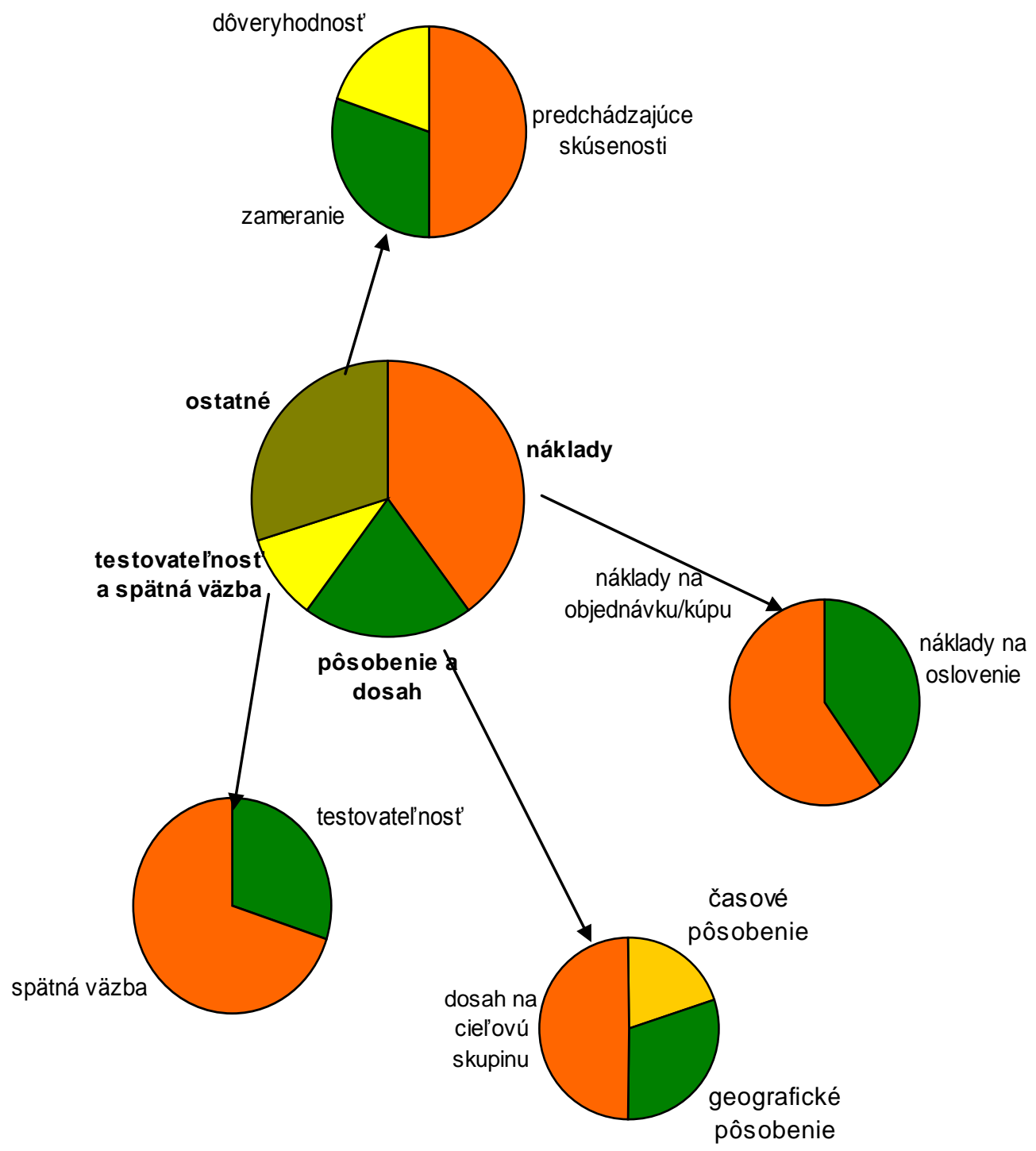

Obrázok 2 Hierarchia kritérií so znázornením ich priorít

Prameň: Vlastné spracovanie.

Váhy vždy volíme tak, aby súčet váh všetkých kritérií bol rovný 1 (t. j. 100\%). Čím je kritérium dôležitejšie, tým má priradenú vyššiu váhu. Za kritérium s najvyššou prioritou boli považované náklady $(40 \%)$, d'alej nasledovali ostatné faktory $(30 \%)$, pôsobenie a dosah (20\%) a nakoniec testovatel'nost' a spätná väzba (10\%). V modelovom príklade sme postupne ohodnotili všetky kritériá, t. j. podskupiny v rámci jednotlivých skupín. Použitú klasifikáciu kritérií možno označit' ako kvalitatívnu (z dôvodu nemožnosti údaje objektívne zmerat' sme 
použili bodovaciu stupnicu od 1 do 4) a zároveň minimalizačnú (najlepšie hodnoty majú najnižšie hodnoty, napr. priemerné až nízke náklady na oslovenie majú hodnotu 1). Hodnotenie jednotlivých kritérií sme uskutočnili na základe individuálnych preferencií, ktoré boli ovplyvnené jednak našim teoretickým bádaním $\mathrm{v}$ danej oblasti ako aj intuíciou. Predpokladáme, že reálne podniky by jednotlivé kritériá hodnotili predovšetkým na základe svojich praktických skúseností. Bližšie pozri tabul'ku 1.

Tabul'ka 1 Hodnotenie jednotlivých kritérií v rámci posudzovaných variantov

\begin{tabular}{|c|c|c|c|c|c|}
\hline $\begin{array}{l}\text { Charakteristika } \\
\text { a hodnotenie } \\
\text { kritérií/variant }\end{array}$ & Reklama & $\begin{array}{l}\text { Podpora } \\
\text { predaja }\end{array}$ & PR & Osobný predaj & $\begin{array}{c}\text { Priamy } \\
\text { marketing }\end{array}$ \\
\hline $\begin{array}{l}\text { Náklady na } \\
\text { oslovenie (40\%) }\end{array}$ & $\begin{array}{l}\text { priemerné až } \\
\text { nízke (1) }\end{array}$ & priemerné (2) & $\begin{array}{l}\text { priemerné až } \\
\text { vysoké (3) }\end{array}$ & vysoké (4) & priemerné (2) \\
\hline $\begin{array}{l}\text { Náklady na } \\
\text { objednávku/kúpu }\end{array}$ & vysoké (3) & priemerné (1) & 0 & vysoké (3) & $\begin{array}{l}\text { priemerné až } \\
\text { vysoké (2) }\end{array}$ \\
\hline $\begin{array}{l}\text { Časové pôsobenie } \\
(20 \%)\end{array}$ & strednodobé (2) & krátkodobé (1) & dlhodobé (3) & strednodobé (2) & dlhodobé (3) \\
\hline $\begin{array}{l}\text { Geografické } \\
\text { pôsobenie (30\%) }\end{array}$ & úplné (2) & obmedzené (1) & úplné (2) & obmedzené (1) & úplné (2) \\
\hline $\begin{array}{l}\text { Dosah na ciel'ovú } \\
\text { skupinu }(50 \%)\end{array}$ & osloví masu (4) & $\begin{array}{l}\text { osloví vybraný } \\
\text { trh. segment } \\
(2) \\
\end{array}$ & osloví masu (4) & $\begin{array}{c}\text { osloví } \\
\text { individuálneho } \\
\text { zákazníka (3) } \\
\end{array}$ & $\begin{array}{l}\text { osloví vybranú } \\
\text { ciel'ovú } \\
\text { skupinu (1) }\end{array}$ \\
\hline $\begin{array}{l}\text { Testovatel'nost' } \\
(30 \%)\end{array}$ & vysoká (1) & vysoká (1) & minimálna (3) & obmedzená (2) & vysoká (1) \\
\hline $\begin{array}{l}\text { Spätná } \quad \text { väzba } \\
(70 \%)\end{array}$ & $\begin{array}{c}\text { sprostredkovaná } \\
\text { (3) }\end{array}$ & $\begin{array}{c}\text { takmer priama } \\
\text { (2) }\end{array}$ & $\begin{array}{c}\text { sprostredkovaná } \\
\text { (3) }\end{array}$ & priama (1) & priama (1) \\
\hline $\begin{array}{l}\text { Predchádzajúce } \\
\text { skúsenosti }(50 \%)\end{array}$ & dobré (2) & $\begin{array}{l}\text { vel'mi dobré } \\
\text { (1) }\end{array}$ & priemerné (3) & priemerné (3) & priemerné (3) \\
\hline $\begin{array}{l}\text { Zameranie } \\
(30 \%)\end{array}$ & na predaj (1) & na predaj (1) & na postoje (3) & na predaj (1) & na predaj (1) \\
\hline $\begin{array}{l}\text { Dôveryhodnost' } \\
(20 \%)\end{array}$ & nízka (3) & priemerná (2) & vysoká (1) & vysoká (1) & priemerná (2) \\
\hline
\end{tabular}

Prameň: Vlastné spracovanie.

Po ukončení párového porovnávania hlavných kritérií a zostavení prvej Saatyho matice, program vypočítal váhy hlavných kritérií v prvej skupine. Analogicky sme postupovali pri všetkých podskupinách kritérií. V príklade sme spolu vytvorili 5 Saatyho matíc (jednu pre hlavné kritériá, štyri pre kritériá druhej úrovne). Hodnoty priorít jednotlivých kritérií modelového príkladu sú uvedené v číselnej podobe vo forme rozhodovacieho stromu na obrázku 3. 


\section{Goal: Optimálny nástroj MK}

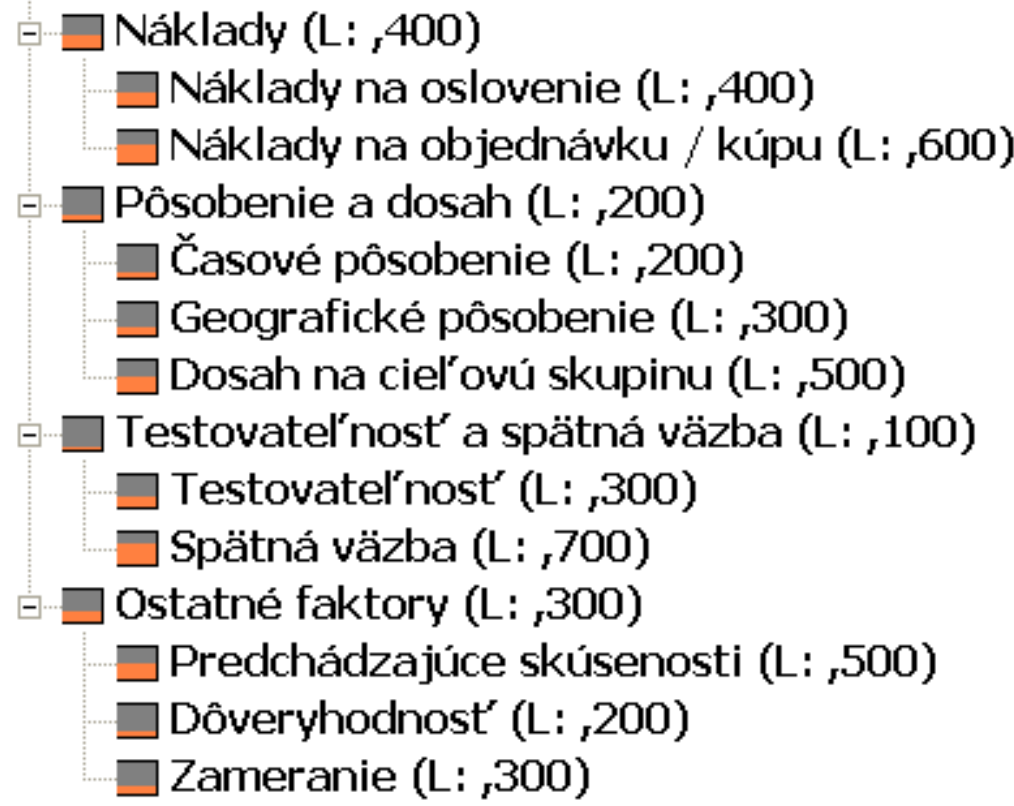

Obrázok 3 Ukážka kriteriálneho rozkladu vo forme rozhodovacieho stromu s váhami kritérií Prameň: Výstup programu Expert Choice.

V d’alšej etape sme z pohl'adu zvolených kritérií vyhodnotili jednotlivé varianty riešenia problému a následne sme stanovili ich poradie. Program Expert Choice pri hodnotení využíva opät' Saatyho metódu (zostavovanie Saatyho matíc), na základe ktorej najskôr vyhodnotí čiastkové utility pre každé kritérium hodnotenia, následne ich násobí váhou príslušného kritéria a umožňuje tak získat' čiastkové vážené hodnotenie (čiastkovú normovanú utilitu). V modelovom príklade sme zostavili spolu 10 Saatyho matíc (jedna matica pre každé čiastkové kritérium). Hodnotenie, ktoré pozostávalo jednak z čiastkového hodnotenia - vyjadrenia čiastkovej utility voči jednotlivým kritériám, ako aj z celkového hodnotenia - vyjadrenia celkovej utility jednotlivých variantov, vyústilo do stanovenia poradia výhodnosti jednotlivých variantov. Ako najvhodnejší nástroj marketingovej komunikácie pre našu modelovú situáciu bola vyhodnotená podpora predaja. V d’alšom poradí to bol priamy marketing, potom reklama a osobný predaj (výsledky sú pomerne tesné). Naopak za najmenej vhodný nástroj pre danú situáciu boli vyhodnotené PR. V komunikačnom mixe nášho hypotetického podniku by preto celkom určite nemala chýbat' podpora predaja a priamy marketing, prípade aj reklama (počet nástrojov sa odvíja od finančných možností podniku). S ohl'adom na namodelovanú situáciu by sa využitie iných nástrojov mohlo prejavit' ako neúčinné a neefektívne.

Program po ukončení jednotlivých výpočtov umožňuje výsledné hodnoty utility zobrazit' vo forme číselných hodnôt a vo forme rozsiahlej škály stípcových alebo čiarových grafov. Ako príklad uvádzame graf 1. 


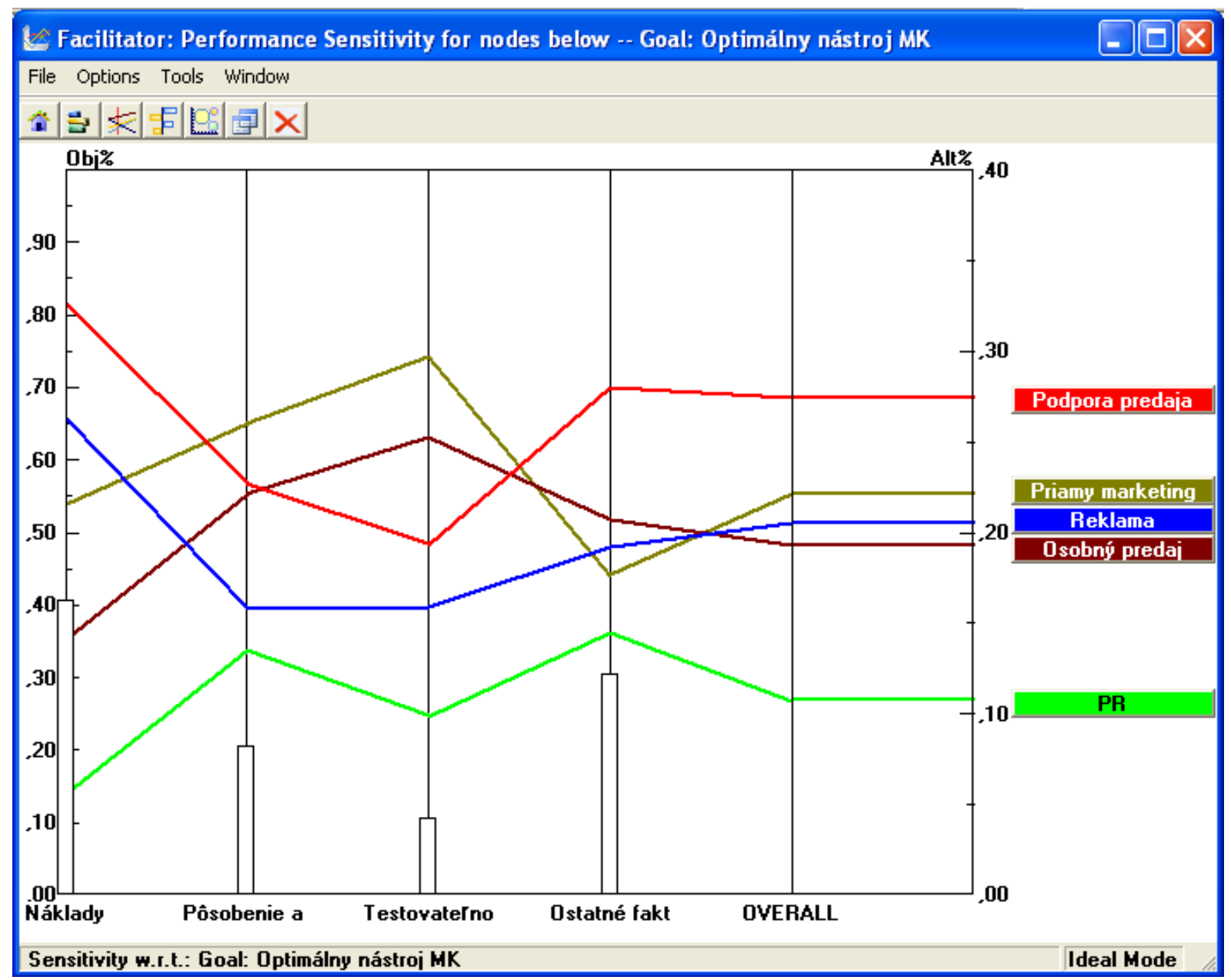

Graf 1 Rozloženie hodnôt preferencií na prvej úrovni rozkladu kritérií

Prameň: Výstup programu Expert Choice.

Program d'alej umožňuje zoradit' varianty z rôznych aspektov a tiež zobrazit' rozloženie hodnôt čiastkových funkcií utility aj pre jednotlivé skupiny kritérií (v jednotlivých uzloch), ako to vidiet' na vyššie uvedenom obrázku. Okrem uvedeného program disponuje aj ovel'a pokročilejšími funkciami. Jeho výhodou je, že získané výsledky môžu byt' d’alej exportované do rôznych dostupných formátov. V rámci komplexnej analýzy program Expert Choice umožňuje modelovat' a simulovat' možné zmeny celkového hodnotenia zmenou hodnôt jednotlivých kritérií, d'alej modelovat' a simulovat' rôzne situácie zmenou parametrov ako aj vykonávat' citlivostnú analýzu. Citlivostná analýza umožňuje sledovat' dynamiku zmien výsledného modelu spôsobenú zmenou jedného, resp. viacerých posudzovaných kritérií. Obrázok 4 ponúka porovnanie pôvodného modelu s novým modelom, ktorý vznikol v dôsledku priradenia vyššej priority/váhy (z 40\% na cca 60\%) kritériu náklady. Z obrázku vidíme, že program automaticky prepočítal váhy všetkých ostatných kritérií, pričom ich pôvodne stanovený vzájomný pomer zostal zachovaný. V novo namodelovanej situácii bola podpora predaja opät’ vyhodnotená ako najvhodnejší nástroj marketingovej komunikácie. V d'alšom poradí však priamy marketing predstihla reklama. 


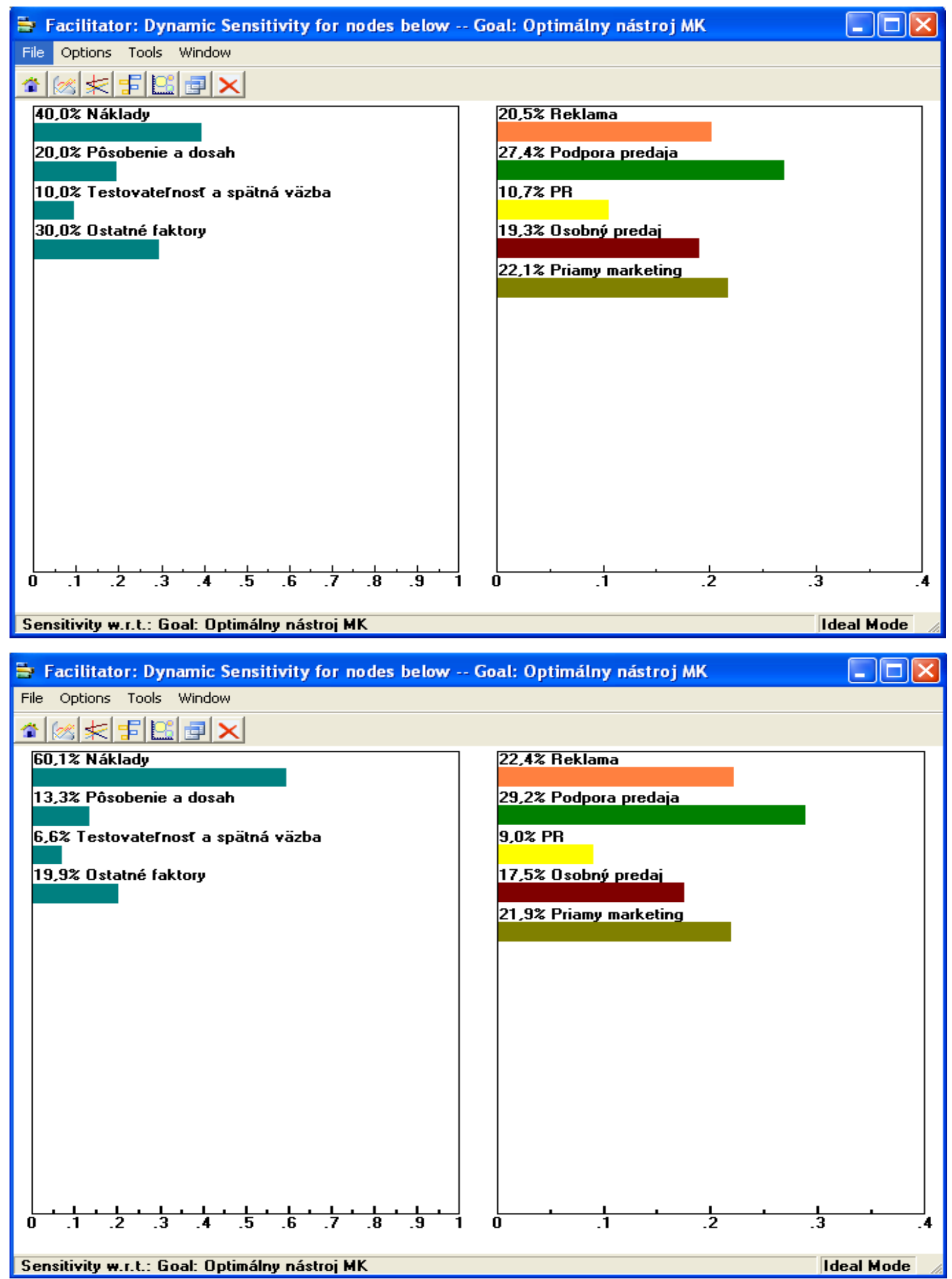

Obrázok 4 Citlivostná analýza dynamiky zmien výsledného modelu Prameň: Výstup programu Expert Choice. 


\section{Záver}

Uplatňovanie optimálneho komunikačného mixu je celkom určite jedným z významných predpokladov realizácie úspešnej a efektívnej marketingovej komunikácie podniku. Ked’že rozhodovanie sa podniku o výbere jednotlivých nástrojov, ktoré budú tvorit' jeho komunikačný mix predstavuje náročný proces hodnotenia rôznych variantov na základe viacerých kritérií, je dobré, ak má podnik k dispozícii nástroje, ktoré by jeho rozhodovanie podporili, resp. ul'ahčili. S ohl'adom na uvedené sme sa rozhodli prostredníctvom modelového príkladu prezentovat' možnosti, ktoré v danej oblasti ponúka program Expert Choice. Okrem podpory pri rozhodovaní sa o strategických nástrojoch komunikačného mixu podniku môže byt' tento program využitý aj pri optimalizácii zdrojov, resp. nákladov na marketingovú komunikáciu, pri strategickom plánovaní marketingovej komunikácie či rozhodovaní sa podniku o konkrétnych formách či médiách. Záverom je potrebné zdôraznit', že uvedený modelový príklad slúži len ako ilustrácia pre možný postup riešenia stanoveného problému. Pričom je potrebné zdôraznit', že ciel'om prezentovaného príkladu nebolo reálne zhodnotit' jednotlivé nástroje marketingovej komunikácie, ale len poskytnút' návod a pomoc pri rozhodovaní a hodnotení jednotlivých variantov. Daný príspevok tiež môže poslúžit' ako zdroj inšpirácie pre všetky podniky, uplatňujúce marketingový koncept riadenia.

\section{Literatúra}

[1] FOTR, J. a kol.: Manažerské rozhodování: postupy, metody a nástroje. Praha: Ekopress 2006, ISBN 80-86929-15-9

[2] REPISKÝ, J.: Teória rozhodovania. Nitra: SPU 2003, ISBN 80-8069-149-5

[3] HEWLET PACKARD, Inc.: Building An Expert Choice Model. Arlington, Virginia 2004

[4] ŠTARCHOŇ, P. a kol.: Marketingová komunikácia 2007. Teória a slovenská prax. Bratislava: Univerzita Komenského v Bratislave 2008, ISBN 978-80-223-24489

[5] KOTLER, P.- ARMSTRONG, G.: Principles of Marketing. New York: Prentice Hall 2007, ISBN 0-13-146918-5

\section{Grantová podpora}

Príspevok je výstupom riešenia projektu VEGA č. 1/4579/07 „Diagnostikovanie hodnotových vzt'ahov a trhových aktivít v podniku“ na Fakulte podnikového manažmentu Ekonomickej univerzity v Bratislave. 